\title{
THE ORIGIN, FATE, AND CYTOCHEMISTRY OF THE GLOBULE LEUCOCYTE OF THE SHEEP ${ }^{1}$
}

\author{
JOHN F. KENT
}

\begin{abstract}
Laboratory of Histology and Embryology, Department of Zoology, Cornell University, Ithaca, New Xork, and Department of Anatcmy, Vniversity of Michigan Medical School, Ann Arbor
\end{abstract}

TWENTY-EIGHT FTGURES

\section{INTRODUCTION}

The "Schollenleukozyt", (Weill, '19) or "globule leucocyte"' (Keasbey, '23) owes its name to the globular, acidophilic inclusions found in variable numbers within its cytoplasm. These cells are most often found within or adjacent to an epithelium. They have been described in the digestive tracts of the sheep (Möller, 1899; Keasbey, '23; Tehwer, '29; Törö, '31; Duran-Jorda, '45), cow (Keasbey, '23; Tehwer, '29; Törö, '31; Duran-Jorda, '45), dog (Möller, 1899; Ferrata, '06; Weill, '19; Lim, '22 ; Törö, '31), cat (Möller, 1899; Muthman, '13; Weill, '19; Lim, '22; Törö, '31; Dawson, '43), mouse (Weill, '19), pig, rabbit (Weill, '19; Lim, '22; Törö, '31), man, horse, guinea pig, bat (Törö, '31), hedgehog (Corti,

\footnotetext{
${ }^{1}$ This study is based on a thesis submitted to the Graduate School of Cornell University in partial fulfillment of the requirements for the degree of Doctor of Philosophy, and was supported by a grant from the Sage Research Fund of the Department of Zoology of Cornell University.

"The most appropriate term. "Globular leucocyte," an unfortunate corruption of Keasbey's term used by Maximow and Bloom ('44), is likely to have a misleading connotation. "Plaque leucocyte," which Keasbey also applied to these cells, and "Schollenleukozyt" both convey an erroneous idea of the shape of the characteristic inclusions of these cells in the sheep. "Leucocytes à mottes" (Weill, '20) and "leucociti a zolle" (Corti, '22) have not been used by later workers.
} 
'22), and various birds (Muthman, '13; Clara, '26; Mjassojedoff, '26; Greulich, '49), reptiles (Törö, '31), amphibia (Corti, '22 ; Törö, '31), and fish (Corti, '22; Rogosina, '28). They have not been reported in the digestive tracts of all vertebrates, however, and are said to be absent in this location in the rat (Weill, '19; Törö, '31), shark ('Törö, '31), and several species of birds (Clara, '26). Moreover, these cells are not always present in the species where they have been described. Möller (1899) did not find them in the digestive tracts of the cow, pig, horse, guinea pig, rabbit, and mouse; Weill ('19) failed to observe them in man and the guinea pig; and Törö ('31) has reported that they are absent in the hedgehog. Although globule leucocytes have not been found above the stomach, in one species or another they. have been observed in all segments of the digestive tube from the stomach through the colon, as well as in the bile and pancreatic ducts, the gall bladder, and Meckel's diverticulum.

Globule leucocytes have also been reported in the mesentery of the turtle (Michels, '23), lymph nodes of irradiated dogs (Dawson, '27), the urinary passageways of the rat (Kirkman, '47, '49, '50), the tracheal epithelium of the cat (Greulich, cited by Kirkman, '50), and, during pregnancy, the endometrium of man (Weill, '20) and the sheep (Wimsatt, personal communication). I have found them within the epithelium on the nasal side of the soft palate of the cat.

There has been considerable disagreement concerning the origin, function, and fate of the globule leucocyte. These cells have been thought to originate from lymphocytes (Weill, '19; A. B. Dawson, '27 ; Michels, '35; H. B. Dawson, '43; and tentatively by Keasbey, '23), certain "mononuclear leucocytes" (Möller, 1899), "wandering cells" (Törö, '29, '31), micromyelocytes (Mjassojedoff, '26), and eosinophilic leucocytes (Clara, '26; Rogosina, '28). According to Jordan ('38) and Kirkman ('50), globule leucocytes may be related to plasma cells with acidophilic inclusions. Only the two Dawsons, however, have presented convincing evidence for their conclusions. 
Various functions have been suggested for these interesting cells. A role in assimilation of food-stuffs has been ascribed to them by Möller (1899), Weill ('19), Clara ('26), Rogosina ('28), and Törö ('31). Keasbey ('23) correlated the occurrence of globule leucocytes with the degeneration of gastric glands near developing lymphatic nodules. On the basis of cytochemical tests and staining affinities, she concluded that the globules contain hemoglobin, but hesitated to call the cells erythrophages. Dawson ('27) also believes the globules are formed within the cells. Michels ('35), however, regards both the globule leucocyte and Russell body cell as erythrophagocytes. Duran-Jorda ('45) thinks that the globules are erythrocytes being synthesized within the globule leucocyte. Kirkman ('47, '49, '50) has found that the occurrence of the globule leucocyte in the urinary passageways of the rat is related to round worm infestation.

The fate of the globule leucocyte has posed a more difficult problem. Because of their scarcity in tissues outside the mucous membrane, and because they do not commonly show degenerative changes, globule leucocytes have been thought to revert to the parent cell type (Möller, 1899; Clara, '26; Rogosina, '28). Corti ('22), Clara ('26), Michels ('35), and Kirkman ('50) have recognized an alternate explanation of these facts - that these leucocytes may pass through the epithelium into the lumen of the organs in which they occur, but have not observed them there.

Because of these conflicting interpretations of the origin, fate, and function of the globule leucocyte, it has seemed worthwhile to reinvestigate the whole problem. This paper presents the first phase of the study - the origin, fate, and cytochemistry of the globule leucocyte of the sheep - a preliminary report of which was made to the American Association of Anatomists in 1949. It is shown that globule leucocytes originate from small lymphocytes rather than from granular leucocytes, plasma cells, or phagocytes, and that they are lost to the body by passing through the epithelium into the lumen of the digestive canal. Additional evidence is 
presented demonstrating that the globule leucocyte is a cell type distinct from the Russell body cell, eosinophilic leucocyte, and erythrophagocyte. The results of cytochemical analysis of the globules, which are in essential agreement with Kirkman's observations, are discussed briefly.

\section{MATERIALS AND METHODS}

The sheep proved most suitable for this investigation. Not only were globule leucocytes regularly abundant in the intestine of this species, but they could easily be differentiated from Russell body cells, known erythrophagocytic cells, and eosinophilic leucocytes in all stages of development. Cytochemical investigation, furthermore, was facilitated by the abundance of large globules in these leucocytes of the sheep.

Ten well-fed, healthy ewes, 9 of which were in various stages of pregnancy, were used. Eight of these were yearlings; two were obviously older, but of unknown age. With the exception of two specimens which were under chloral hydrate anesthesia when the tissues were removed, the animals were killed by exsanguination and the first tissues removed within 5 minutes after death.

Of a variety of fixing solutions used, Bouin's, Zenker-acetic, and Helly's Zenker-formol fluids were most satisfactory. For studying the morphology and distribution of the globule leucocytes, the most useful stains were a modified Dominici technique, Maximow's hematoxylin eosin-azure stain, and iron and phosphotungstic acid hematoxylins.

The Golgi apparatus was demonstrated by the DaFano silver impregnation method. A modified Benda technique, following Champy fixation, was used to stain mitochondria. In the interests of brevity, the cytochemical methods used will be indicated in discussing the results of these tests.

\section{OBSERVATIONS}

\section{Morphology}

In the digestive passageways of the sheep, globule leucocytes vary in diameter from 5 to $6 \mu$ in the young, lymphocyte- 
like stages up to 10 to $12 \mu$ in the largest mature cells. They appear to be motile, and not only show elongated, pseudopodia-like processes, but are often irregularly shaped because of the varied situations into which they insinuate themselves.

The spherical or ovoid nucleus of the globule leucocyte resembles the "Radkern" of the lymphocyte and typically occupies an eccentric position within the cell. Irregularly shaped nuclei are not common and except when pyknotic (an uncommon occurrence), or in cells containing exceptionally large globules, are not caused by globules impinging on the nucleus, as is often the case in the dog and rabbit (Weill, '19) and in the Russell body cell. In the sheep as in most other forms in which these cells occur, globule leucocytes undergoing mitosis (fig. 12) are rarely observed.

The cytoplasm of the mature globule leucocyte of the sheep typically shows no affinity for the usual stains (figs. 8-11) the condition described by Keasbey ('23) - or, more rarely, is faintly acidophilic. By staining intensely, however, it is possible to demonstrate that the cytoplasm is irregularly vacuolated (figs. 12, 14). In leucocytes densely packed with globules, the cytoplasm is difficult to demonstrate clearly, but it seems reasonable to conjecture that in such cells, the vacuoles are either absent or much reduced in size.

In mature cells, the characteristic globular inclusions may vary in number from 6 to 8 up to several dozen and are predominantly homogeneous, acidophilic, refractile spherules (figs. 8-11). Irregularly shaped globules do occur, but I have never observed the cup-shaped, biconcave, and crenated forms which Keasbey ('23) described in the sheep. A few or all of the globules in a cell may show a dark-staining outer zone which blends into a chromophobic inner portion (figs. $12,14)$. Globules are also found containing one or more sharply defined vacuoles (fig. 8), or, usually in very large globules, a mass of smaller, closely packed vacuoles. Although these less common nonhomogeneous types of globules occur in most preparations, the fact that the frequency with which they appear is affected by the method of fixation indicates 
that these appearances of the globules may be artifacts. Alcohol and acetone fixation do not preserve the globules, but permit them to rupture and diffuse into the cytoplasm causing it to become strongly acidophilic. It should be noted, however, that this dissolution of the globules and the laking of nearby erythrocytes do not, as Keasbey ('23) says, always go hand in hand, but following the use of appropriate fixing solutions, either effect may be produced independently of the other.

Both mitochondria and Golgi material are demonstrable in the cytoplasm of the globule leucocyte. The former occur as granules or short rods, and in mature cells, may be found either closely applied to the globules or free in the cytoplasm (fig. 14). A similar picture has been described by Kirkman ('50) in the globule leucocytes of the urinary passageways of the rat. Golgi material may be found in the globule leucocytes of the intestine of the sheep as strands scattered throughout the cytoplasm. In some cells, there is a cap of such material next to the nucleus (fig. 15). Greulich (unpublished observations reported by Kirkman, '50) has demonstrated Golgi material in the globule leucocytes of the fowl.

\section{Distribution}

In the alimentary canal of the sheep, globule leucocytes normally occur in the abomasum, the large and small intestines, and the caecum. Keasbey ('23) has, in addition, reported a single exceptional occurrence in the rumen. Everywhere in these organs, the distribution of globule leucocytes is highly irregular (figs. 27, 28). Concentrations of them are distributed at random throughout the mucous membrane and both in these and in more diffusely populated areas, variable numbers of the cells are situated within the connective tissue (where Keasbey ['23] "seldom, if ever," found them) and the epithelia of the surface and glands.

The most irregular distribution is found in the abomasum. As reported by Keasbey ('23), globule leucocytes are rarely 
present in the cardiac region of the stomach. Considerable numbers of them may be present in the peptic abomasum, but often it contains few or none. I have found the same variation in the pyloric region, where Keasbey reported them almost uniformly abundant. Globule leucocytes are restricted to the mucosa in all parts of the abomasum, but beyond this I observed no pattern of distribution.

The intestine almost invariably contains globule leucocytes throughout its length. I found them regularly present in large numbers in the duodenum, and usually abundant in the remainder of the small intestine, in the colon, and in the caecum. This same distribution is described by Möller (1899). Keasbey ('23), on the other hand, reports only small numbers of globule leucocytes in the duodenum and jejunum, and found them below this point in only a single sheep, where they were present in the ileum. Globule leucocytes in the intestine are restricted to the mucosa except in the region of Brunner's glands in which a few of them usually occur.

In addition to the globule leucocytes found in the alimentary tube itself, numbers of them may often be seen in the cystic and common bile ducts and a few are usually to be encountered in the lining epithelium of the gall bladder.

\section{Development of the globule leucocyte}

In the intestine of the sheep, globule leucocytes originate from small lymphocytes situated in the mucosa, where a complete series of intermediate stages may be found. The earliest recognizable stages of this transformation are typical small lymphocytes containing one or more acidophilic spherules in their basophilic cytoplasm (figs. 1-3). As development progresses, the cytoplasm becomes more and more vacuolated (fig. 5), loses its basophilia, and becomes acidophilic or refractory to staining (fig. 6). As still more globules accumulate, both these inclusions and the mitochondria, which at first aggregated about the centrosome (figs. 4-6, 13), become dispersed throughout the cytoplasm (figs. 7-11, 14). After a 
considerable number of medium-sized globules have accumulated, further enlargement of the globules tends to be accompanied by a decrease in their number, and by a greater variation in size from the largest to the smallest within the same cell. This, together with the occasional occurrence of globules containing several denser areas or several distinct groups of vacuoles, suggests that in these more mature stages, the globules enlarge by coalescence as well as by the addition of new material. Dawson ('43) has also found evidence of coalescence, but Kirkman ('50) believes this process is an artifact of fixation.

Although all stages in the development of globule leucocytes may be found in both the connective tissue and epithelial layers of the alimentary mucosa, the younger ones are much more frequently encountered in the tunica propria, and the more mature cells within the epithelium. Thus it would appear that most of these leucocytes originate in the loose connective tissues, and, as they mature, migrate into the epithelium. The abundance of mature cells in this location suggests that they remain within the epithelium for some time. That they may return to the tunica propria and "degranulate," passing through the same stages as developing cells, is theoretically possible, but there are too few immature cells to support this view. In addition, although Keasbey ('23) has reported that "there is nothing to show that globule cells ever approach a lumen ....," globule leucocytes often lie well above the level of the nuclei of the epithelium (fig. 23), at the surface (fig. 24) where both Dawson ('43) and Kirkman ('50) have seen them, and in rare instances they may be found in the act of entering the lumen (fig. 25). Numerous globule leucocytes are contained in the layer of mucous overlying areas of mucosa densely populated with them and a few may be found in the lumen of gastric and intestinal glands. Changes in the staining reactions and morphological features of these cells indicate that they are destroyed after entering the lumen. 


\section{Cytochemical observations}

Cytochemical methods were used primarily to elicit further information concerning the nature of the globules and to supplement the morphological differences between the globule leucocyte and those cell types most likely to be confused with it. In the cases of the Russell body cell, erythrophagocyte, and eosinophile, only those reactions which seemed to be of cytotaxonomic significance have been reported.

The globule leucocyte. The presence of iron in the globules (Keasbey, '23) was confirmed by the Perls Prussian blue (Lillie, '48) and Tirmann-Schmelzer Turnbull blue (Lison, 36) reactions and by examination of incinerated sections under the dark field microscope. No other part of the cells gave reactions for iron, and it must be concluded that the nuclear reaction Keasbey obtained following sulfuric acid "demasquage" was an adsorption phenomenon (cf. Lison, '36). In the urinary passageways of the rat (Kirkman, '50) and in the gall bladder of the cat (Dawson, '43) globule leucocytes do not give positive reactions for iron.

Despite the presence of iron in the globules, and the fact that Keasbey ('23) obtained the Okajima reaction in them, they gave neither the Lison ('36) stable peroxidase nor the Dunn-Thompson (Lillie, '48) staining reaction for hemoglobin, although erythrocytes in the sections invariably did so. In the hen, these cells also fail to give positive reactions for hemoglobin (Greulich, '49), but in the rat, although they do not give a positive stable peroxidase reaction, the Hirschler and Okajima tests for hemoglobin are positive (Kirkman, '50).

In the sheep, as in the fowl (Greulich, '49) and rat (Kirkman, '50), stable oxidase (M-nadi oxidase - Lison, '36) and labile peroxidase (Loele benzidine and Loele alphanaphthol Lison, '36) reactions were consistently negative in all constituents of the globule leucocytes. Dawson ('43) has reported that globule leucocytes in the cat do not give a positive peroxidase reaction. Keasbey ('23) obtained a posi- 
tive peroxidase reaction in both the globules and erythrocytes by prolonging the treatment but I have been unable to duplicate her results.

The enzyme phosphatase, which Kirkman ('50) did not find in the globule leucocytes of the rat, is present in all components except the vacuoles of these cells in the sheep (method of Gomori, '41). ${ }^{3}$

Tests for radicals commonly found in amino acids and proteins were generally positive in the nucleus and cytoplasm of the globule leucocytes. The globules gave a weakly positive biuret (Serra, '46) reaction for peptide linkage and a positive reaction for arginine (method of Serra, '46) in the sheep, but give neither reaction in the rat (Kirkman, '50). Tyrosine, if present in the globules, probably occurs in low concentration since the Millon (Serra, '46), xanthoproteic (Lison, '36), and basic azo (Lison, '36) reactions for phenolic compounds were all negative. If Serra ('46) is correct in his interpretation of the last test, histidine may also be absent or present in only small amounts. In the rat, the globules differ in giving a positive xanthroproteic reaction (Kirkman, '50). Tryptophane likewise may not be an important constituent of the globules, for the indophenine (Lison, '36) test for pentagonal heterocyclic compounds was negative. The globules gave only a faint ferric-ferricyanide (Chevremont and Frederie, '43) reaction, comparable to that of most of the other tissues in the sections; therefore, sulfhydryl containing compounds do not appear to be present in any great concentration. Kirkman ('50) also failed to demonstrate sulfhydryl compounds in globule leucocytes of the rat.

The globules of the globule leucocyte stain metachromatically with dilute aqueous toluidine blue. Since this metachromasia is neither abolished nor diminished by digestion with $0.02 \%$ hyaluronidase as suggested by Wislocki, Bunting and Dempsey (' $47 \mathrm{~b})$, it is not caused by hyaluronic acid. After

\footnotetext{
${ }^{3}$ Because alcohol and acetone are unsatisfactory fixatives for the globules, tissues for this reaction were fixed in cold formalin-acetic-alcohol (Bodian formula no. 2) which also preserved the enzyme well.
} 
salivary digestion and periodic acid oxidation, the globules recolorize leucofuchsin. These observations are in agreement with those of Kirkman ('50) who, having also demonstrated the absence of ribonucleic acid, believes that an acid mucopolysaccharide is responsible for the metachromatic staining properties of the globules.

In the cytoplasm of the globule leucocytes found in the intestine of the sheep, glycogen was almost invariably demonstrated by the periodic acid-leucofuchsin (Lillie, '48) technique following Pasteels-Leonard (Lison, '36) fixation. Neither Greulich ('49) nor Kirkman ('50) found glycogen in the globule leucocytes they studied.

The globules of the globule leucocytes are not sudanophilic. The cytoplasm of these cells, however, contains small particles, stainable with Sudan black B, which appear to be either Golgi material or mitochondria. Since pyridine extraction does not prevent a positive Baker ('46) acid hematein reaction in the globules, phospholipids, if present in them, are bound to a protein substrate. It was not possible to determine whether or not the sudanophilic particles in the cytoplasm were phospholipids because, if they gave the acid hematein reaction, they were obscured by the dark-staining globules. Kirkman ('50) has made similar observations on the lipids in globule leucocytes in the rat.

Russell body cells. In the sheep, Russell body cells do not give reactions for iron. As Kirkman ('50) has pointed out, however, these cells may contain demonstrable iron in some species. Stable peroxidase and the Dunn-Thompson staining methods for hemoglobin were negative in the Russell bodies as in the globules. Unlike the globules, Russell bodies gave a positive Millon reaction for phenolic compounds and a strongly positive indophenine reaction for pentagonal heterocyclic compounds and failed to stain metachromatically. Neither glycogen nor lipids were observed in Russell body cells or their inclusions.

Erythrophagocytic cells. Erythrophagocytes were studied in the spleen of the sheep. Erythrocytes, whether free or 
recently ingested by phagocytes, gave at the most very faint Prussian blue or Turnbull blue reactions for iron. Particles of phagocytized erythrocytes in later stages of disintegration, however, gave strong reactions with these tests for iron, and, in the terminal stages of digestion, the reactions were not confined to the fragmented erythrocytes, but occurred diffusely throughout the pigmented cytoplasm of the phagocyte. This was true even after Bouin or Zenker fixation. Neither free nor ingested erythrocytes were observed to stain metachromatically.

Eosinophilic leucocytes. In the sheep, as in most other animals, eosinophilic leucocytes contain both oxidase and peroxidase, and the granules are stained intensely by tests for these enzymes. The eosinophile granules also differ from the globules of the globule leucocyte in containing sudanophilic lipid that gives a positive Baker phospholipid reaction which is prevented by extraction in pyridine (cf. Wislocki and Dempsey, '46). Unlike the globules, the granules of the easinophile of the sheep (like those of man-Wislocki, Bunting and Dempsey, '47a) do not give reactions for iron, nor do they stain metachromatically with toluidine blue.

\section{DISCUSSION}

It is difficult to be certain of the species distribution of the globule leucocyte. Inadequate descriptions and illustrations, the variety of techniques which have been used in preparing the materials studied by different investigators and the resemblances sometimes found between these and other cells (Russell body cells, eosinophilic leucocytes, plasma cells with acidophilic inclusions, and phagocytes containing acidophilic particles), all contribute to the probability that several types of cells have, at one time or another, been classified as globule leucocytes. The evidence for their occurrence in the digestive tracts of the sheep, cow, dog, cat, mouse, and in birds and in the respiratory tract of the cat is clear. In the pig and rabbit, it is possible that the cells Weill ('19) described are globule leucocytes even though they are somewhat unique 
in certain of their morphological characteristics. Kirkman's ('50) descriptions of globule leucocytes in the urinary passage ways of the rat leave no doubt concerning their identity.

Reports of globule leucocytes in other species and situations must be accepted with considerable reservation until further work has been done. The reports of these cells in man, the guinea pig, bat, turtle, crocodile, frog, salamander (Törö, '31) are supported by neither illustrations nor adequate descriptions. The globule leucocytes which Törö has described in the horse, moreover, were undoubtedly eosinophilic leucocytes, which, because of their relatively enormous inclusions in this species, somewhat resemble globule leucocytes. The cells which Zibordi ('20) has described in the hemopoietic organs of the dog, and which Corti ('22) believes to be globule leucocytes are obviously eosinophilic leucocytes which, in this animal, have granules of irregular and often considerable size.

Cells similar to those which Rogosina ('28) has described in the ganoid fish are found in the alimentary mucosa of many fish (literature reviewed by Duthie, '39). In a number of species of fish, however, Duthie has shown that these cells occur in the blood stream and blood-forming organs, that the staining reactions of the granules of immature stages change during maturation, and that within the epithelium of the digestive passageways, disintegrative changes often appear in these cells and their granules. Since none of these characteristics are found in the globule leueocyte, it is possible that in the fish, granular leucocytes may have been described as globule leucocytes.

Michels ('23) has observed what appear to be globule leucocytes in the mesentery of the turtle. Because globule leucocytes have been found so regularly in mucous rather than serous membranes, however, further investigation of these cells would be of interest.

Doctor A. B. Dawson of Harvard University has very kindly permitted me to examine his preparations of lymph nodes of irradiated dogs. The cytoplasm of the cells which he described as globule leucocytes in these tissues has stained 
readily (figs. 16-18), is not vacuolated, but is often separated from the acidophilic inclusions by a shrinkage space (figs. $16,17)$. All these characteristics may be found in the Russell body cells of the sheep (figs. 20-22), but are not typically observed in the intestinal globule leucocytes of either the sheep or the dog. Further investigation is needed to determine whether these are atypical globule leucocytes, or are more akin to the Russell body cell. Apparently identical cells from the lymph nodes of irradiated rabbits and from syphilitic condylomata have been pictured by Michels ('35; fig. 15, cells 20-25; fig. 16), who identifies them as Russell body cells.

On the basis of morphology alone, the cells which Wimsatt has shown me in the uterus of the sheep are typical globule leucocytes. Asplund and Holmgren ('47), however, have objected to Weill's ('20) identification of similar cells in the uterus of man as globule leucocytes. This problem, therefore, should be given further study.

The morphology and cytochemistry of the globule leucocyte show that it is a cell type distinct from the eosinophilic leucocyte, Russell body cell, and erythrophagocytes, the only three cells likely to be confused with it in the intestine of the sheep. The eosinophilic leucocyte, although it also has acidophilic granules and may be found within the epithelium of the digestive tract, is clearly differentiated from the globule leucocyte on the basis of its inclusions alone. The granules of the eosinophile of the sheep are smaller than the smallest globules of the globule leucocyte and resemble flattened platelets rather than spherules (fig. 19). In addition, the granules of the eosinophilic leucocyte contain lipids and are strongly stained following oxidase and peroxidase tests; none of these reactions is given by the globule leucocyte or its globules. Iron and metachromatic materials, characteristically found in the acidophilic inclusions of the globule leucocytes of the sheep, are lacking in the granules of the eosinophile.

The Russell body cells in the intestinal mucosa of the sheep are also easily distinguished from the globule leucocytes. After being stained by either the Dominici technique 
or the Maximow technique, the cytoplasm of the Russell body cell, unlike that of the mature globule leucocyte, is definitely basophilic and, although shrinkage spaces frequently surround the inclusions, it is not vacuolated (figs. 20-22). Although Russell bodies and globules may stain similarly with many techniques, all Russell bodies are colorless or yellowish following phosphotungstic acid hematoxylin, whereas the globules of the globule leucocytes are stained a dark blue. In the sheep Russell body cells and globule leucocytes may also be distinguished from each other by the failure of the Russell bodies either to stain metachromatically or to give positive tests for iron. The Russell bodies, but not the globules, also contain phenolic and pentagonal heterocyclic compounds.

Both free and phagocytized erythrocytes differ from the globules of the globule leucocytes in a number of respects. Free erythrocytes can be stained with Sudan black, give a positive acid hematein reaction for phospholipids, and in the material studied, always gave the stable peroxidase and Dunn-Thompson reactions for hemoglobin. Were the globules of globule leucocytes phagocytized erythrocytes, it is most probable that at least a few globules which had very recently been ingested would be found to give one or more of these reactions. No globule, however, was ever observed to give any of them. Erythrocytes ingested by phagocytes, furthermore, do not stain metachromatically as do the acidophilic inclusions of the globule leucocyte. Erythrocyte fragments in later stages of digestion within phagocytes differ from the globules also in being strongly pigmented and, in most organs where they are found, in giving positive reactions for iron more readily. The cytoplasm of phagocytes containing such fragments, unlike that of the globule leucocyte, is likely to contain diffuse iron-bearing pigment.

Globule leucocytes have been supposed to transport proteinaceous food-stuffs (in the form of globular inclusions) from the intestinal lumen into the mucous membrane. Opposed to this is the evidence that the vast majority of the globule leucocytes found in the intestine originate in the 
tunica propria and, as they mature, migrate into the epithelium, through which they pass into the intestinal lumen. This is the reverse of what would be expected if they play the role postulated. In addition, their occurrence in the urinary passageways (Kirkman, '47, '49, '50), respiratory passageways (Greulich, personal communication cited by Kirkman, '50), the gall bladder (Dawson, '43), and possibly in lymph nodes (Dawson, '27), the mesentery (Michels, '23), and the uterus (Weill, '20; Wimsatt, personal communication) can hardly be explained on this basis.

The hypothesis that globule leucocytes secrete erythrocytes (Duran-Jorda, '45) has been disposed of adequately by Kirk$\operatorname{man}(' 50)$.

The possibility that the globules of the globule leucocyte are phagocytized erythrocytes (Michels, '35) must be reexamined because this conclusion is based on Keasbey's ('23) observations of crenated, biconcave, and cup-shaped globules (which were not found at all in the material studied during this investigation), on her descriptions of similarities in staining reactions between the globules and erythrocytes (resemblances shown only by certain techniques), on her identification of hemoglobin in the globules (which is questionable), and on the assumption that Russell body cells and globule leucocytes are very similar, if not identical cells (whereas on the basis of morphology, staining reactions, and cytochemistry, they are quite distinct). The cytochemical findings already discussed oppose the possibility that the globules of the globule leucocytes are phagocytized erythrocytes. Additional evidence strengthens this conclusion. The tissues in which Michels studied the Russell body cell contained abundant extravasated erythrocytes. In the abomasum and intestine, however, as Weill ('19), Keasbey ('23), and Clara ('26) have already pointed out, erythrocytes are probably very rarely available to the globule leucocytes. It is unlikely that erythrocytes extravasated into the connective tissue are the source of the globules since such extravasation was not observed in the intestine of the sheep. The masses of "free globules" 
which Keasbey ('23) saw in the epithelium and interpreted as possible erythrocytes were found by Möller (1899) and myself to be globule leucocytes whose nuclei did not fall within the section. It is also improbable that the globules represent erythrocytes ingested intravascularly, for even the youngest stages of these leucocytes show no predilection for the vicinity of vascular channels. In addition, globule leucocytes have never been described in the blood-stream of the sheep (Scarborough, '31-'32).

Although Keasbey ('23) believed there was a relationship between the occurrence of globule leucocytes and tissue degeneration in the vicinity of developing lymphatic nodules, I have found only a negligible portion of these leucocytes situated in the vicinity of lymphatic nodules, and have never observed the engorged, necrosing capillaries, which Keasbey described as frequent in areas abundantly populated with globule leucocytes.

A relationship between the occurrence of globule leucocytes and parasitic infestation, as Kirkman ('47, '49, '50) has found in the urinary passageways of the rat, could be neither established nor disproved in the intestine of the sheep. Numerous round worms, usually embedded in the crypts of Lieberkühn, were found in the sections. Their occurrence, however, could not be related to the concentration of globule leucocytes; some parasites were located in areas rich in these cells, others were in areas containing few or none. In the latter cases, the parasites may not yet have exerted their effect. Furthermore, most sites containing high concentrations of globule leucocytes showed no evidence of round worms; but whether these had been exposed to the influence of parasites present in the ingesta could not be determined. Nor could any relationship be established between the occurrence of globule leucocytes and the presence of nodular worms encysted in the muscularis externa of the intestine. Nevertheless a relationship between the development of globule leucocytes and parasitic infestation in the digestive passageways is an attractive possibility. It could explain both 
the irregular distribution of high concentrations of globule leucocytes within a given individual and the sometimes inconsistent occurrences of these cells in a species. This problem, therefore, must be considered carefully in further investigations of these cells.

Present knowledge concerning the conditions causing the development of the globule leucocyte is too scanty to permit drawing any definite conclusions concerning their functional significance. It might be tentatively suggested, however, that these cells arise, not in response to a specific stimulus, but as a reaction to substances of various origins which diffuse into the mucous membranes in the situations where the globule leucocytes are found. Parasites may be one source of such substances.

\section{SUMMARY}

1. Both morphologically and cytochemically the globule leucocytes or "Schollenleukozyten" of the abomasum and intestine of the sheep are shown to be distinct from eosinophilic leucocytes, Russell body cells, and erythrophagocytic cells.

2 . In the gastro-intestinal tract, globule leucocytes originate from small lymphocytes, usually in the tunica propria, migrate into the epithelium in large numbers, and eventually pass out into the lumen where presumably they are destroyed.

3. The cytoplasm of the globule leucocyte is highly vacuolated until, in the oldest cells, it becomes closely packed with globules. It contains glycogen and shows alkaline phosphatase activity, but does not give reactions for peroxidase, oxidase, iron, metachromatic materials, and lipids other than mitochondria and Golgi material.

4. The acidophilic globules of these leucocytes have been shown to be proteinaceous, and to contain iron, arginine, and metachromatic substances. Hemoglobin, phenolic and pentagonal heterocyclic compounds, glycogen, and lipids are not demonstrable in them.

5. Present evidence indicates that the globule leucocytes do not aid in the assimilation of food-stuffs, nor do they phago- 
cytize erythrocytes. There does not appear to be any relationship between developing lymphatic nodules and the occurrence of globule leucocytes.

6. It is tentatively suggested that globule leucocytes may arise as a reaction to the diffusion of substances of various origins into the mucous membranes. Whether or not parasites were one source of these substances in the sheep could not be determined.

\section{ACKNOWLEDGMENTS}

The encouragement and counsel of Dr. Howard B. Adelmann of Cornell University, so generously given during the investigation and preparation of the manuscript, are acknowledged with deep gratitude. I am also indebted to Dr. William A. Wimsatt of Cornell University for his ever ready and valuable advice, and for making it possible to use the sheep for this investigation.

\section{LITERATURE CITED}

Asplund, J., AND HJ. HoLmGRgN 1947 On the oceurrence of metachromatically granulated cells in the mucous membrane of the human uterus. Acta Anat., $3:$ 312-330.

BAKER, J. R. 1946 Histochemical recognition of lipine. Quart. J. Micr. Sei., $87: 441-447$.

Chevremont, M., and J. Frederic 1943 Une nouvelle méthode histochimique de mis en évidence des substances à fonction sulfhydrile. Areh. de Biol., 54: 589-605.

Clara, M. 1926 Beiträge zur Kenntnis des Vogeldarms. VI Teil. Das lymphoreticuläre Gewebe im Darmrohre mit besonderes Berüeksichtigung der leukozytären Zellen. Ztschr. f. mikr.-anat. Forsch., 6: 305-350.

Cortr, A. 1922 Contributo alla determinazione specifica delle cellule mononucleate migrante nel epithelio intestinale et allo studio delle loro funzioni. Haematologica, 3: 121-150.

DAwson, A. B. 1927 Modified lymph nodes from dogs with a known history of irradiation, including a note on "globule" leucocyte formation. Anat. Rec., 36: 1-29.

Dawson, H. B. 1943 A study of certain cells observed in the gall bladder mucosa of cats. Anat. Rec., 85: 135-155.

Duthie, E. S. 1939 The origin, development and function of the blood cells in certain marine teleosts. Part I. Morphology. J. Anat., 73: 396-411. 
DURAN-JORDA, F. 1945 Local haemopoiesis as seen in the abomasum of the cow and sheep. Vet. J., 101: 191-194.

Frrrata, A. 1906 Sui globuli bianchi mononucleati. Arch. per le sei. med., $30: 217-249$.

Gomorr, G. 1941 The distribution of phosphatase in normal organs and tissues. J. Cell. and Comp. Physiol., 17: 71-83.

Greulich, R. C. 1949 Intestinal Schollenleukozyten in the chieken. Anat. Rec., 103: 571. (Abstract.)

JoRD $\Lambda$, H. E. 1938 Comparative hematology. In Handbook of Hematology (2), H. Downey, ed. Hoeber, New York, 808-810.

KEasbey, J. E. 1923 On a new form of leucocyte (Schollenleukozyt, Weill) as found in the gastrie mucosa of the sheep. Fol. Haemat., 29: 155-173.

Kent, J. F. 1949 A reinvestigation of the origin, fate, and eytochemistry of the globule leucocyte (Schollenleukozyt). Anat. Rec., 103: 474-475. (Abstract.)

KIRKMAN, H. 1947 Intraepithelial cells in urinary tracts of rats infested with Trichosomoides crassicauda. Anat. Rec., 97: 349. (Abstract.)

1949 Urinary Schollenleukozyten in albino rats. Anat. Ree, 103: 575. (Abstract.)

$1950 \Lambda$ comparatire morphological and eytochemical study of globule leucocytes (Schollenleukocyten) of the urinary tract and of possibly related cells. Am. J. Anat., 86: 91-131.

LILlif, R. D. 1948 Histopathologic Technique. Blakiston, Philadelphia.

LIM, R. K. S. 1922 The gastric mucosa. I. The gastric mucosa of the cat. Quart. J. Micr. Sci,, 66: 187-203.

Lison, L. 1936 Histochimie animale. Méthodes et Problèms. Gauthier-Villars, Paris.

Maximow, A. A., And W. Bloom 1944 Textbook of Histology. W. B. Saunders, Philadelphia.

Michels, N. A. 1923 The mast cell in the lower vertebrates. La Cellule, 33: $339-462$.

1935 Medullary and non-medullary erythropoiesis with special reference to the plasma-cell erythrophage or Russell body cell, and to the erythrocatheretic (erythrolytic) function of lymph nodes and hemal nodes. Am. J. Anat., 57: 439-501.

MJassojedoff, S. W. 1926 Die Zellformen des Bindegewebes und des Blutes und die Blutbildung beim erwachsenen Huhn. Fol. Ilacmat., 82: 263-296.

MöLler, W. 1899 Anatomische Beiträge zur Frage von der Sekretion und Resorption in der Darmschleimhaut. Ztsehr. f. wiss. Zool., 66: 66-135.

Muthuan, E. 1913 Beiträge zur vergleichenden Anatomie des Blinddarmes und der lymphoiden Organe des Darmkanals bei Säugetieren und Vögeln. Anat. Hefte, 48: 65-114. 
Rogosina, M. 1928 Beiträge zur Kenntnis des Verdauungskanals der Fische. I. Ueber den Bau des Epithels im Pylorusabschnitt des Magens von Acipenser Ruthenus L. Ztschr. f. mikr.-anat. Forsch., 14: 333-372.

SCARBorough, R. A. 1931-32 The blood picture of normal laboratory animals. Yale J. Biol. and Med., 3: 359-373, 547-552; 4: 69-82, 199-206.

SERRA, J. A. 1946 Histochemical tests for proteins and amino acids; the characterization of basic proteins. Stain Technol., 21: 5-18.

Twrwwer, J. 1929 Beiträge zur Kenntnis der Histologie der Duodenaldrüsen bei den Haussäugetieren. Ztsehr. f. mikr.anat. Forseh., 18: 71-92.

Törö, E. 1929 Ueber enterochromaffine Zellen. Anat. Anz., 67: Ergänsungsheft, $49-58$.

1931 Bedeutung und Entstehung der Zellgranula in der Darmresorption. Ztschr. f. Anat. u. Entwick, 94: 1-38.

WEILL, P. 1919 Uebex die leukozytären Flemente der Darmschleimhaut der Säugetiere. Arch. f. mikr. Anat., 93: 1-81.

1920 Études sur les leucocytes. I.- Les cellules granuleuses des muqueuses intestinale et uterine. Arch. d'Anat. Micr., 17: 77-82.

Wislocki, G. B., H. Bunting and E. W. DEmpsey 1947 a Further observations on the chemical cytology of megakaryocytes and other cells of hemopoietic tissues. Anat. Rec., 98: 527-538.

$1947 \mathrm{~b}$ Metachromasia in mammalian tissues and its relationship to mucopolysaccharides. Am. J. Anat., 81: 1-38.

Wislocki, G. B., AND E. W. IEMPSEy 1946 Oljservations on the chemical cytology of normal blood and hemopoietic tissues. Anat. Rec., $96: 249$ 278.

Zıbord, D. 1920 Su un particolare reperto nei lencociti eosinofili del cane. Haematologica, 1: 450-453. 


\section{PLATE 1}

\section{EXPLANATION OF FTGTRES}

All illustrations, unless otherwise specified, are of tissues from the sheep stained with hematoxylin eosin-azure or with the Dominici teahnique. The cells in figures 1-22 were outlined with the camera lueida $\times 1600$. Figures $1-11,13-22$ were drawn at $\times 5000$ and are reproduced at $\times 2500$, whereas figure 12 was drawn at $\times 3200$ and is reproduced at $\times 1600$.

1-10 Developmental stages of the globule leucocyte. 1-4. Early lymphocytelike cells with basophilic cytoplasm. 5, 6. Later immature cells showing the beginning of vacuolation of the cytoplasm and the loss of cytoplasmic basophilia. 7. Transitional cell in which the globules have lost their orientation. 8-11. Mature globule leucocytes showing progressive enlargement of the globules. No attempt has been made to select cells illustrating the tendency of the globules to decrease in number as they increase in size. (1-3, 7-11 from duodenum; 4, 5 from ileum; 6 from jejunum.)

12 Globule leucocyte in mitosis. This eell, showing a polar view of the metaphase plate, is one of three globule leucocytes seen in division during the investigation. Duodenum; acid hematein stain.

13, 14 Young and mature globule leucocytes showing the change in distribution of mitochondria as the colls mature. Peptic abomasum; crystal violet, picric acid stain.

15 Golgi material in globule leucoeyte from the duodenum. DaFano silver impregnation, Dominici stain.

16-18 Leucocytes with globular inclusions from lymph node of irradiated dog. (Preparation by Dr. A. B. Dawson, Harvard University.) Hematoxylin and eosin stain.

19 Eosinophilic myclocyte from ileum.

20-22 Russell body cells from intestine. (Twenty from ileum; 21 from duodenum; 22 from colon.) 

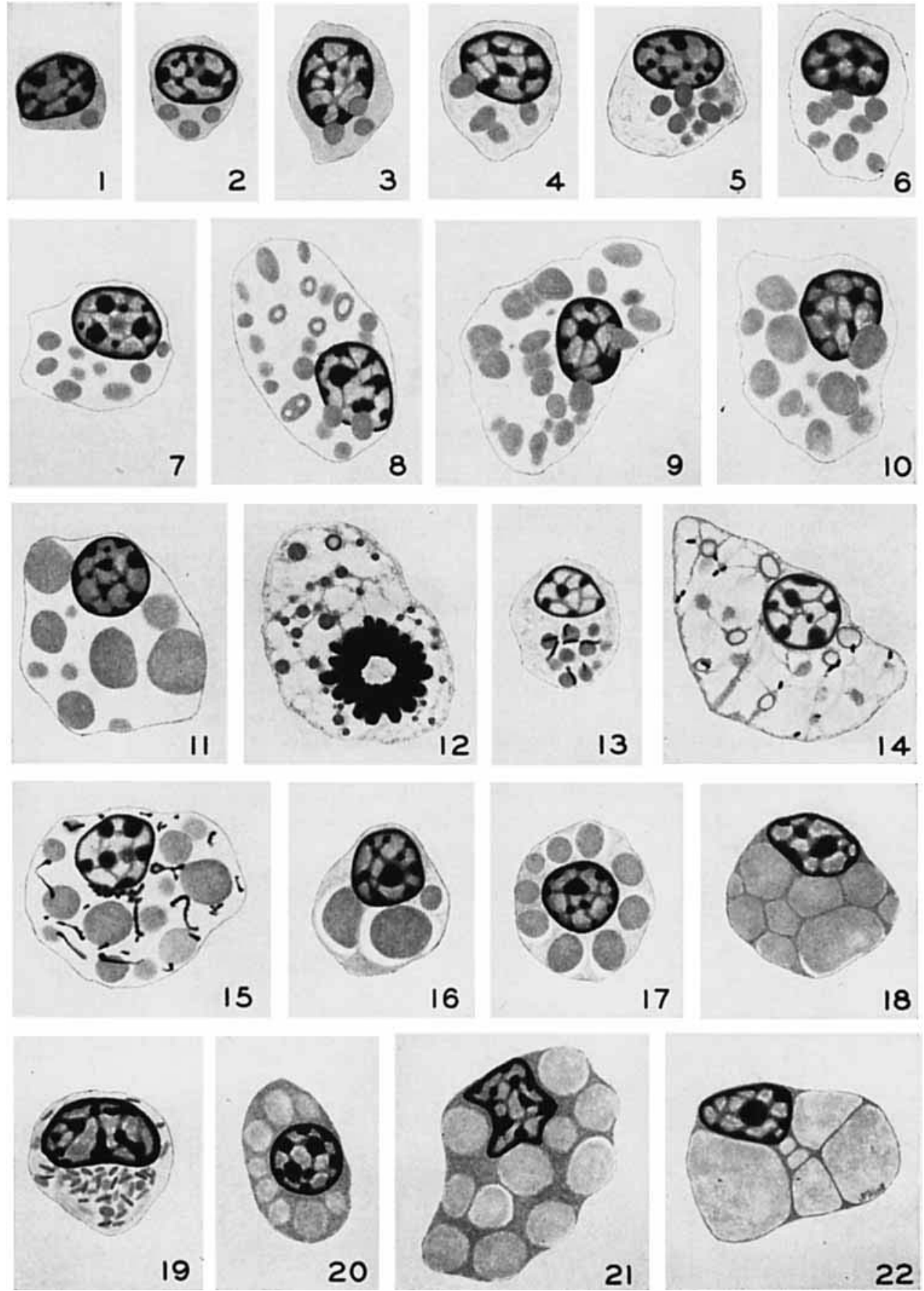
PLATE 2

EXPLANATION OF FIGURES

23 Globule leucocytes passing through the epithelium of a duodenal villus. $\times 980$.

24-25 Globule leucocytes in various stages of penetrating the surface epithelium of the peptie abomasum. In 25, the epithelium shows the space once occupied by the globule leucocyte in the lumen adjacent to it. $\times 980$.

26 Globule leucocytes from the duodenum fixed in weak Bouin's solution. Many of the globules show the "hollow sphere" appearance. Acid hematein stain. $\times 1000$.

27 Few of the globule leucocytes in this area, a few millimeters from figure 28, are in the surface epithelium. Although most of these cells are shown in the epithelium lining the duct of a Brunner's gland, in other areas they are just as likely to lie in the epithelium of the crypts. $\times 150$.

28 Globule leucocytes in the mueosa of the duodenum. Most of the globule leueocytes in this area lie in the surface epithelium and only a few in the crypts of Lieberkühn. $\times 150$. 

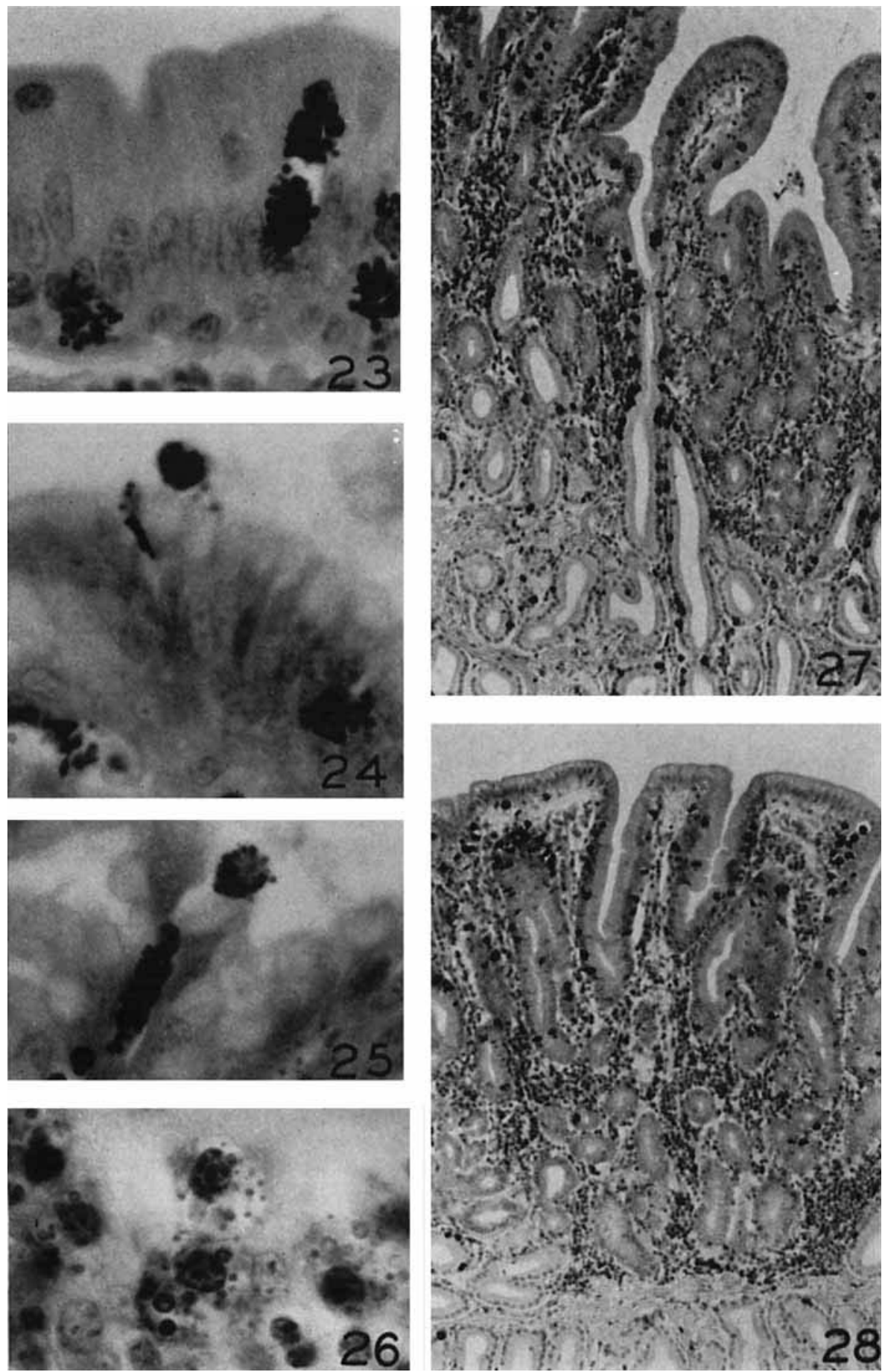